\title{
Relationship between geology and landslide occurrence in the Sor Range, Quetta, Pakistan
}

\author{
Abdul Tawab Khan \\ Department of Geology, University of Balochistan, Quetta, Pakistan \\ (Email: atk298@yahoo.com)
}

\begin{abstract}
The Sor Range is situated about $16 \mathrm{~km}$ east of Quetta in the axial zone west of the Sulaiman Thrust-Fold Belt. It contains sedimentary rocks ranging in age from Jurassic to Recent. The Ghazij Formation of Early Eocene is divided into the Lower, Middle, and Upper Members, respectively. The Kirthar Formation of Late Eocene age is divided into the Habib Rahi Limestone and Serki Member. The Siwaliks of Miocene to Pleistocene age consist of the Nagri, Dhok Pathan, and Soan Formation (Urak conglomerate) and are overlying the Kirthar Formation with an unconformity.

Landslide susceptibility mapping was carried out on a scale of 1:50,000. This study describes various ancient and active landslides in the area and fissures developed in the Ghazij Formation that cover an area of about $130,000 \mathrm{~m}^{2}$. There are also several hundred metres long and very wide fissures in the dip slope of the Kirthar Formation. The widespread instabilities are confined to the fold belts as well as major wrench and thrust faults, and they were triggered or reactivated by earthquakes
\end{abstract}

\section{INTRODUCTION}

The Sor Range lies about $16 \mathrm{~km}$ east of the Quetta district of Balochistan, Pakistan. It falls on the topographic map No. $34 \mathrm{~N} / 4$ between latitude $30^{\circ} 00^{\prime}: 30^{\circ} 15^{\prime} \mathrm{N}$ and longitude $67^{\circ} 00^{\prime}: 30^{\circ} 15^{\prime} \mathrm{E}$ (Fig. 1). Detailed field mapping on a scale of $1: 50,000$ revealed various lithostratigraphic units and structural features as well as many landslides and tension cracks, especially in the vicinity of coal mines.

The study area is situated in a semiarid zone. The relief of the area is irregular and highly mountainous. The main stream, which runs parallel to the road, is known as the Obushtakai Nala. The investigated area is drained by a small portion of three other streams. One of them is situated at the northernmost part of the mapped area and is known as the Ush Bul Nala (Fig. 2, 3). The rocks belonging to the Soan Formation (Urak Conglomerate) and Kirthar Formation make high and prominent peaks due to their resistance to erosion. The Sor Range exhibits elongated ridges and narrow valleys with steep slopes. Frequently, the peaks reach an altitude of $2100 \mathrm{~m}$. The present work attempts to come up with a relationship between the landslide occurrence and the textural as well as structural features of rock formations in the area.

\section{LITHOSTRATIGRAPHY}

The investigated area is located between the Kirthar and Suleiman Belts at the edge of the Quetta Syntaxis, and is

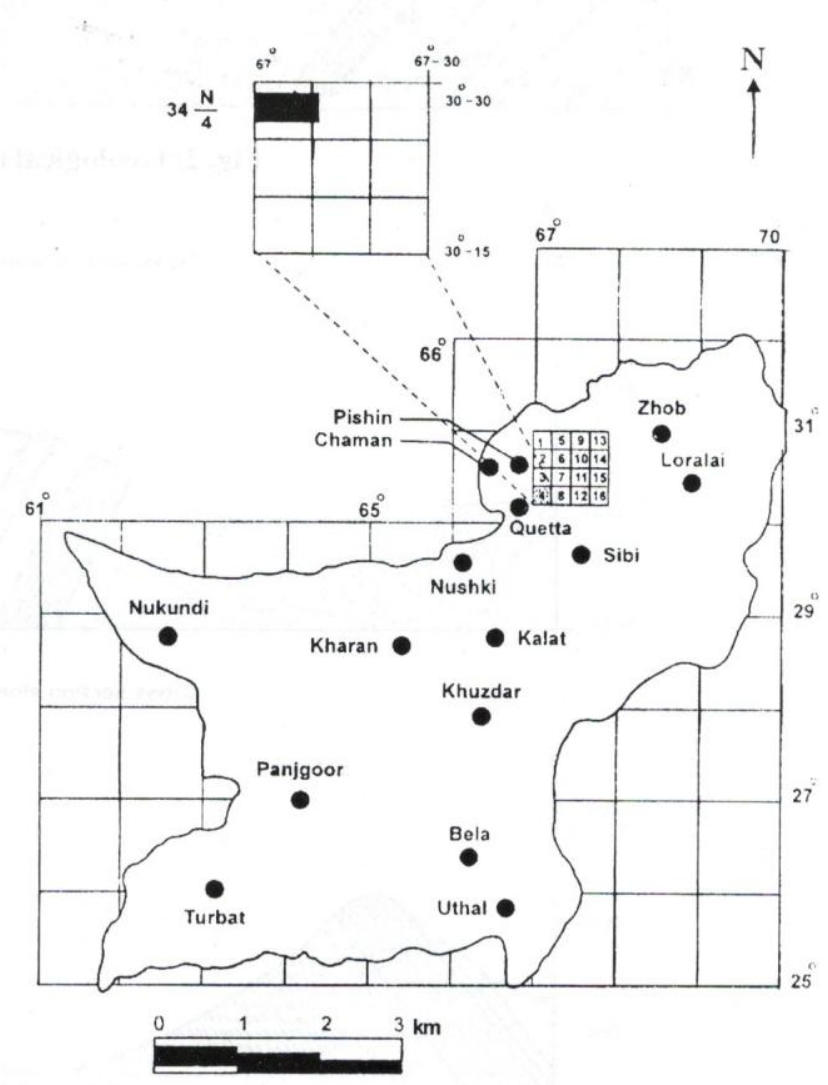

Fig. 1: Index map of the Sor Range 
Abdul Tawab Khan
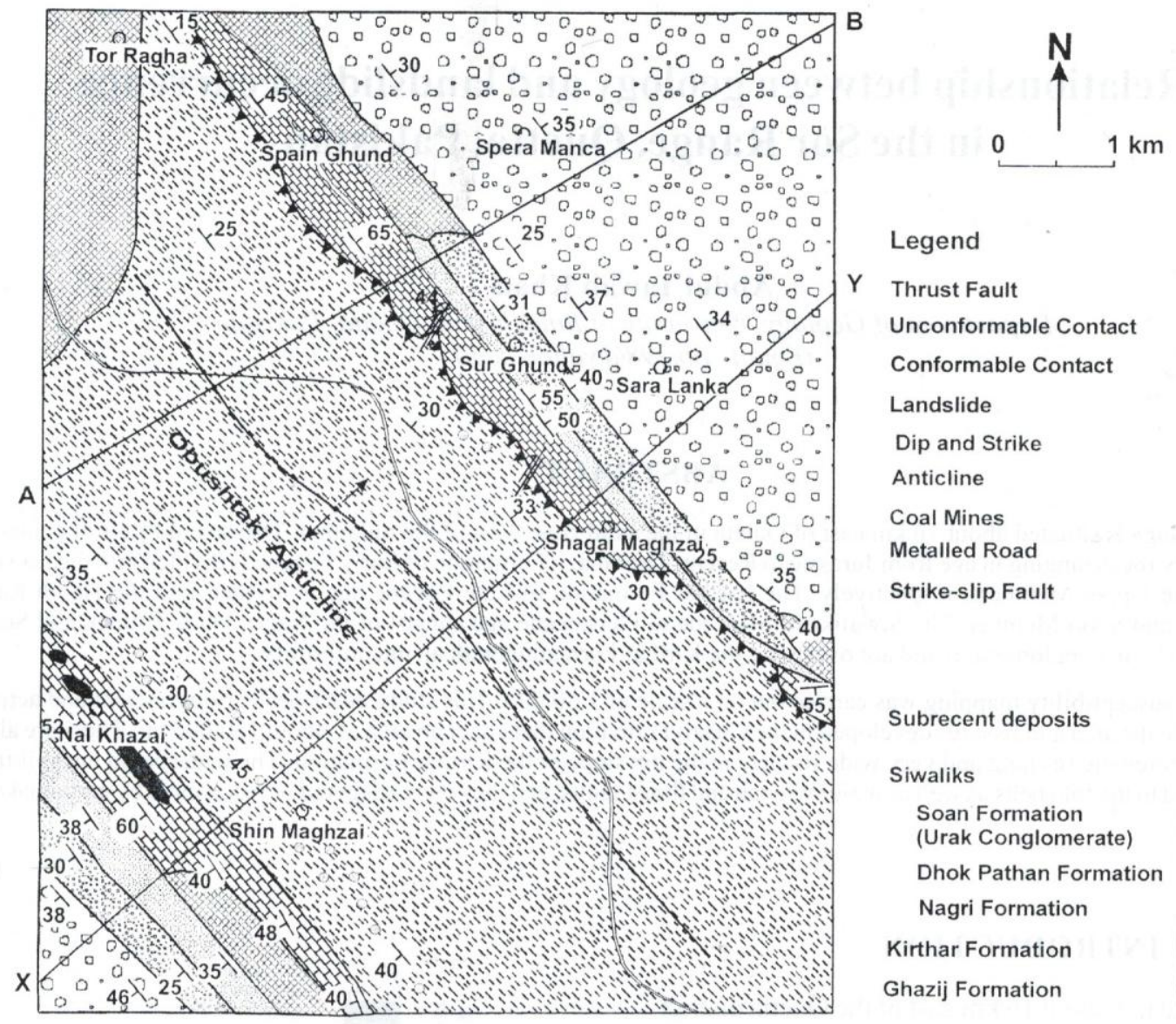

\section{Legend}

Thrust Fault

Unconformable Contact

Conformable Contact

Landslide

Dip and Strike

Anticline

Coal Mines

Metalled Road

Strike-slip Fault

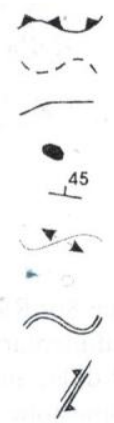

Subrecent deposits

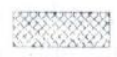

\section{Siwaliks}

Soan Formation

(Urak Conglomerate)

Dhok Pathan Formation

Nagri Formation

Kirthar Formation

Ghazij Formation

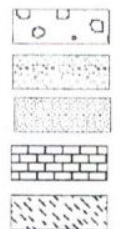

Fig. 2: Geological map of the Sor Range
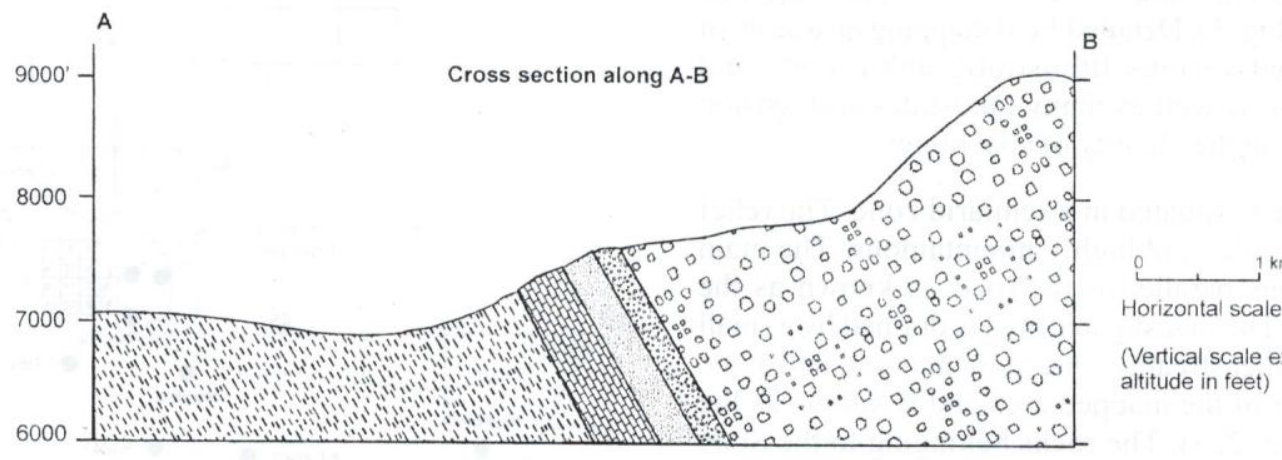

Horizontal scale

(Vertical scale exaggerated altitude in feet)

Cross section along $X-Y$

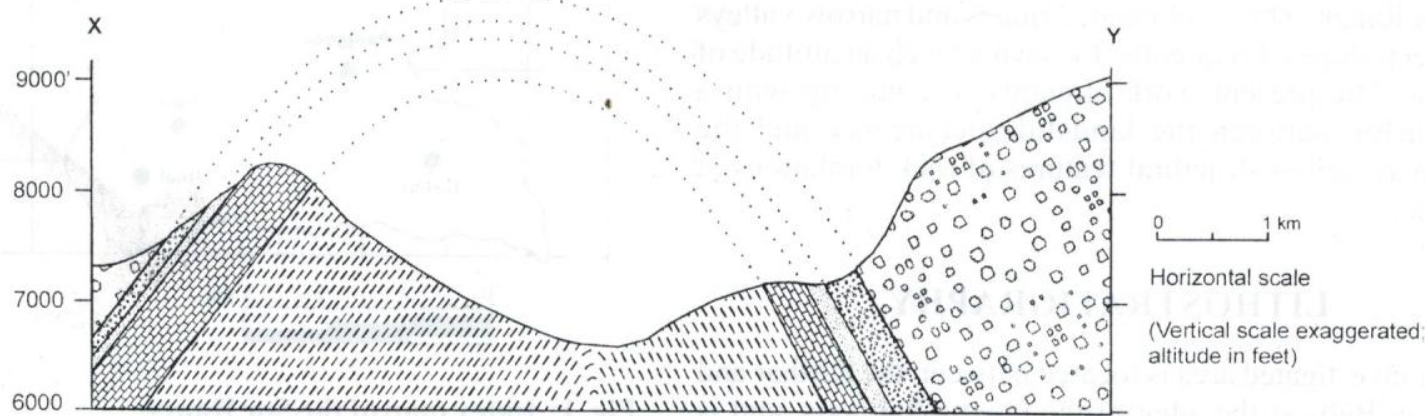

Fig. 3: Geological cross-sections along lines $\mathrm{AB}$ and $\mathrm{XY}$ in Fig. 2 


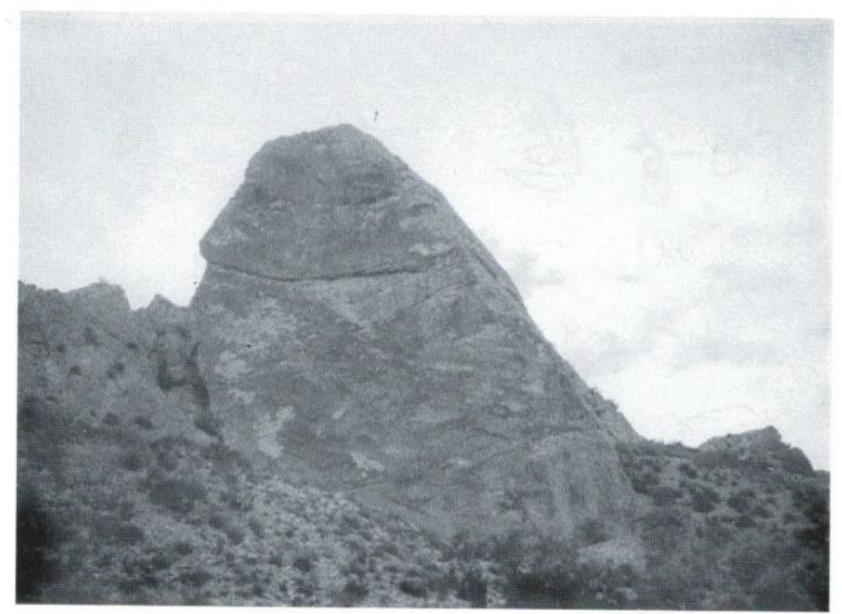

Fig. 4a: Conglomerate bed in the Ghazij Formation of the Sor Range

part of the axial zone. The sedimentary rocks ranging in age from Jurassic to Pleistocene are made up of limestone, shale, conglomerate, and sandstone (Kakar and Kassi 1997). These rocks are subdivided into the following formations and members, respectively from bottom to top (Table 1).

\section{Ghazij Formation}

The Ghazij Formation of Early Eocene age is the lowest lithostratigraphic unit of the study area. Williams (1959) redefined the Ghazij Formation from its type section at Spin Tangai $\left(59^{\circ} 57^{\prime} \mathrm{N}\right.$; $\left.68^{\circ} 05^{\prime} \mathrm{E}\right)$ in the Ziarat district. It is subdivided into the Lower, Middle, and Upper Members (HSC 1960). In the study area, the Lower Ghazij consists predominantly of shale, claystone, siltstone, and thin-bedded sandstone. The siltstone is green-grey to olive grey-green and the sandstone is green to grey-green. The incompetent Ghazij Formation is highly susceptible to erosion, and forms high-angle concave-up slopes and smooth hills.

The Lower Ghazij Member is about $780 \mathrm{~m}$ thick in the study area (Mohsin et al. 1991). The Middle Ghazij Member consists of shale, siltstone, coal, and conglomerate (Fig. 4a). The shale is green-grey to pale yellow, calcareous, and sporadically gypsiferous. The sandstone is grey to light grey and medium- to coarse-grained. The conglomerate is present in the upper part of the Member as a marker bed. It is thick-bedded and consists of cobbles and pebbles of limestone (Fig. 4a). The conglomerate clasts are well rounded and poorly sorted. They are cemented by sandy matrix and their clast size ranges from $3 \mathrm{~mm}$ to $28 \mathrm{~cm}$. A few sub-bituminous coal seams are present in the Middle Member. The thickness of the lowermost coal seam is up to $1 \mathrm{~m}$, while the topmost one is up to $2 \mathrm{~m}$, but at some localities the thickness varies from 4 to $6 \mathrm{~m}$. Bioturbation, cross-bedding, ripple marks, and sole marks are common in the sandstone (Fig. 4b). The U pper Ghazij Member is made up of shale, claystone, and sandstone. It extends from the above conglomerate to the overlying Kirthar Formation. The pale yellow, pale green, and light red claystone is silty and calcareous. The
Table 1: Stratigraphic succession of the study area

\begin{tabular}{|c|c|c|}
\hline Formation & Lithology & Age \\
\hline Alluvium & $\begin{array}{l}\text { Sandstone, siltstone, } \\
\text { conglomerate, boulders, and } \\
\text { cobles of limestone }\end{array}$ & Recent \\
\hline $\begin{array}{l}\text { Soan } \\
\text { Formation }\end{array}$ & $\begin{array}{l}\text { Pebbles and boulders of } \\
\text { different colors cemented } \\
\text { sandstone, siltstone and clay }\end{array}$ & $\begin{array}{l}\text { Pliocene to } \\
\text { Pleistocene }\end{array}$ \\
\hline $\begin{array}{l}\text { Dhok } \\
\text { Pathan } \\
\text { Formation }\end{array}$ & $\begin{array}{l}\text { Radish brown shale, } \\
\text { sandstone and brown } \\
\text { claystone }\end{array}$ & $\begin{array}{l}\text { Early to } \\
\text { Middle } \\
\text { Pliocene }\end{array}$ \\
\hline $\begin{array}{l}\text { Nagri } \\
\text { Formation }\end{array}$ & $\begin{array}{l}\text { Medium- to fine-grained } \\
\text { sandstone of greenish colour } \\
\text { cross-bedded and laminated }\end{array}$ & $\begin{array}{l}\text { Middle } \\
\text { Miocene }\end{array}$ \\
\hline $\begin{array}{l}\text { Serki } \\
\text { Member } \\
\text { Limestone }\end{array}$ & $\begin{array}{l}\text { Limestone of brownish grey, } \\
\text { shale inter-bedded with } \\
\text { medium- to coarse-grained, } \\
\text { calcareous sandstone of dark } \\
\text { brown colour }\end{array}$ & Late Eocene \\
\hline $\begin{array}{l}\text { Habib Rahi } \\
\text { Limestone }\end{array}$ & $\begin{array}{l}\text { Hard and thick bedded, light } \\
\text { grey sandstone. At some } \\
\text { places fine-grained, veins of } \\
\text { calcite are also present }\end{array}$ & Late Eocene \\
\hline $\begin{array}{l}\text { Upper } \\
\text { Ghazij }\end{array}$ & Shale, clay, and sandstone & Early Eocene \\
\hline $\begin{array}{l}\text { Middle } \\
\text { Ghazij }\end{array}$ & $\begin{array}{l}\text { Shale, siltstone, thick-bedded } \\
\text { conglomerate and Coal }\end{array}$ & Early Eocene \\
\hline $\begin{array}{l}\text { Lower } \\
\text { Ghazij }\end{array}$ & $\begin{array}{l}\text { Shale, claystone, siltstone and } \\
\text { thin-bedded sandstone }\end{array}$ & Early Eocene \\
\hline
\end{tabular}

sandstone is medium- to coarse-grained, moderately to poorly sorted, rounded to well rounded, and well cemented. Cross-laminae and ripples are also present (Fig. 4c). The upper contact of the Ghazij Formation is conformable with the Habib Rahi Limestone and the lower contact is not exposed in the Sor Range.

\section{Kirthar Formation}

The term Kirthar is derived from the name of the Kirthar Range. The type section lies in the Gaj River in the Kirthar Range. In the investigated area, the Kirthar Formation of Late Eocene age has only two members as described below.

The name, Habib Rahi Limestone was given to the lower part of the Kirthar Formation, which is $158-201$ m thick. It is light grey to cream coloured at fresh surfaces and pale yellow to grey-brown at weathered surfaces. The limestone is thick-bedded with rough bounding surfaces, hard, compact, and highly fossiliferous. The limestone is mainly coarsely crystalline, but is of fine-grained at some places.

The upper portion of the Kirthar Formation is called the Serki Member. In the investigated area, it includes limestone and shale interbedded with medium-to coarse-grained 


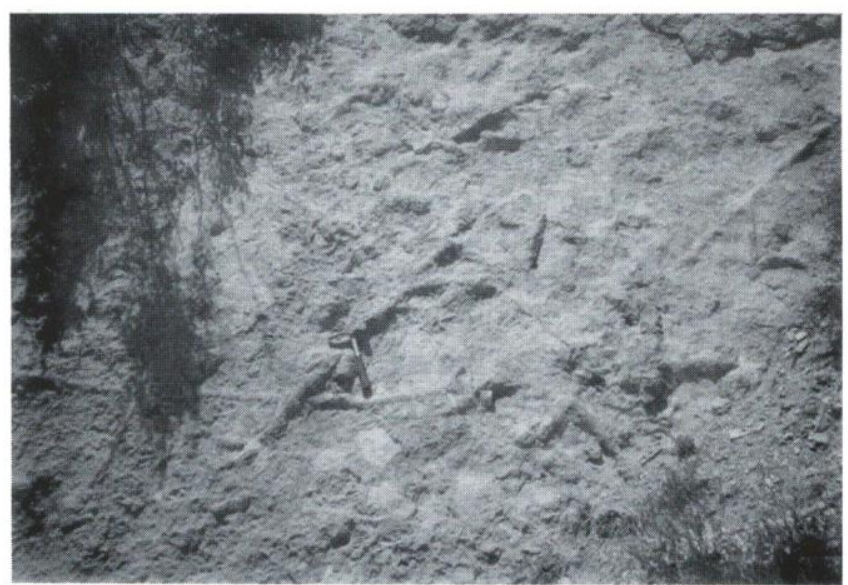

Fig. 4b: Bioturbation at the top of the Habib Rahi Limestone of the Kirthar Formation

calcareous sandstone. The shale is fine-grained and is browngrey to dark brown in colour and at some places it is also yellow to pale yellow-brown. The sandstone from the Serki Formation contains fine- to coarse-grained gypsiferous beds grey, brown, dark brown, and reddish brown in colour. The Serki Member is about $250 \mathrm{~m}$ thick.

The lower contact of the Serki Member with the Habib Rahi Limestone is conformable and transitional, whereas the upper contact with the Nagri Formation is unconformable.

\section{Siwalik Group}

The Siwalik Group of Middle Miocene to Pleistocene age is divided into the Chinji, Nagri, Dhok Pathan, and Soan Formations. In the investigated area, only the last three formations are exposed.

The Nagri Formation is derived from the village of Nagri situated in the Campbellpore district. In the investigated area, the local name for the Nagri Formation is the Uzdah Pusha Formation (Kazmi 1979). This formation is composed of green-grey and light grey, medium- to fine-grained sandstone. The sandstone is rich in lithic fragments with a minor amount of quartz and feldspar as well as muscovite and biotite (Kassi 1987). In the sandstone, cross-laminae, cross-bedding (Fig. 5b), and ripple marks are also found. It is loosely packed. Its upper contact with the Dhok Pathan Formation is transitional.

The Dhok Pathan Formation was redefined by Shah (1977) from the Dhok Pathan village in the Attock district, where it has been designated as the type section. In the study area, it comprises alternating beds of clay shale and sandstone (Fig. 5a). The sandstone is brown-grey to reddish brown coloured, moderately to well sorted, fine- to mediumgrained, and sporadically pebbly. The clay is reddish brown, red, maroon, and sandy. In many places, pebbly sandstone is also present. The lower part of the formation includes thin

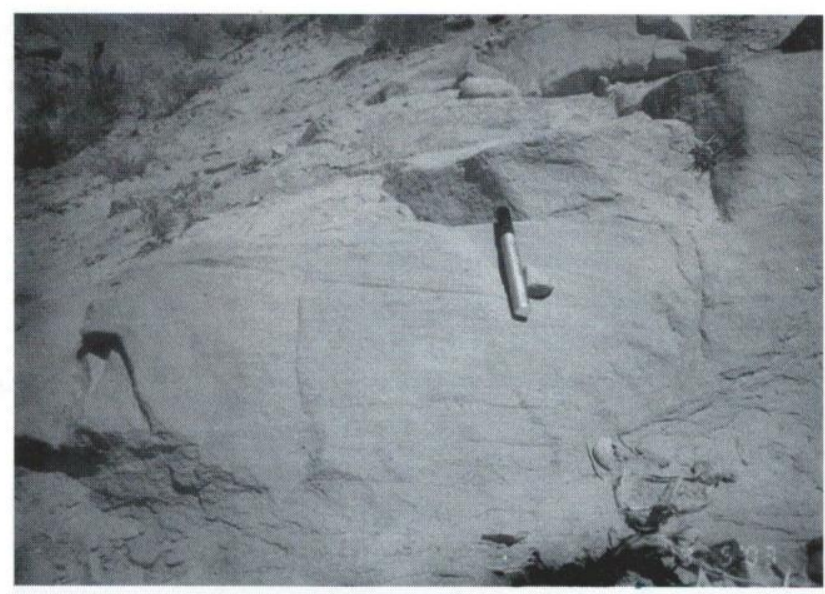

Fig. 4c: Parallel lamination and low-angle cross lamination in a sandstone bed of the Nagri Formation

parallel beds of sandstone, thickness of which ranges from $2 \mathrm{~cm}$ to $1 \mathrm{~m}$. Sedimentary structures such as cross-bedding, ripple marks together with joints and fractures are common. Bioturbation holes of 2 to $5 \mathrm{~cm}$ length are also encountered (Fig. 4b). The upper contact of the Dhok Pathan Formation is transitional with the overlying Soan Formation.

The type section of the Soan Formation is located in the Soan River, the Campbellpore district. The section near the Urak village in the Quetta district is proposed as the principal reference section. In the investigated area, the Soan Formation consists of compact and massive conglomerate with interbeds of sandstone, siltstone, and mudstone. The cobbles and pebbles of conglomerate are in clay and sandy matrix (Fig. 2). The imbricate pebbles in the matrix-supported sandstone show the palaeoflow direction. The thickness of conglomerate beds ranges from $64 \mathrm{~cm}$ to $2 \mathrm{~m}$. The sandstone beds of the Soan Formation contain feldspar and quartz. The rock is hard, compact, and an individual bed thickness is about $6 \mathrm{~cm}$. There are also a few light grey mudstone and claystone beds, in which compactly arranged concretions are found. The upper contact of the Soan Formation is conformable with the Recent deposits. The age of the Soan Formation ranges from Late Pliocene to Pleistocene.

\section{ENVIRONMENT OF DEPOSITION}

The lithological characteristics and fossil occurrence in the above rocks suggest a shallow marine to deltaic environment of deposition. The Ghazij Formation was deposited in a deltaic environment (HSC 1960; Kakar and Kassi 1997), where the lower claystone and siltstone were derived from the prodelta clays of marine origin. Transgression of the Tethys Sea took place during the time of deposition of the Kirthar Formation containing the Habib Rahi Limestone Member in its lower part and the Serki Member in the upper part. After that, the area was tectonically uplifted and in the Oligocene epoch the extensive deposition 


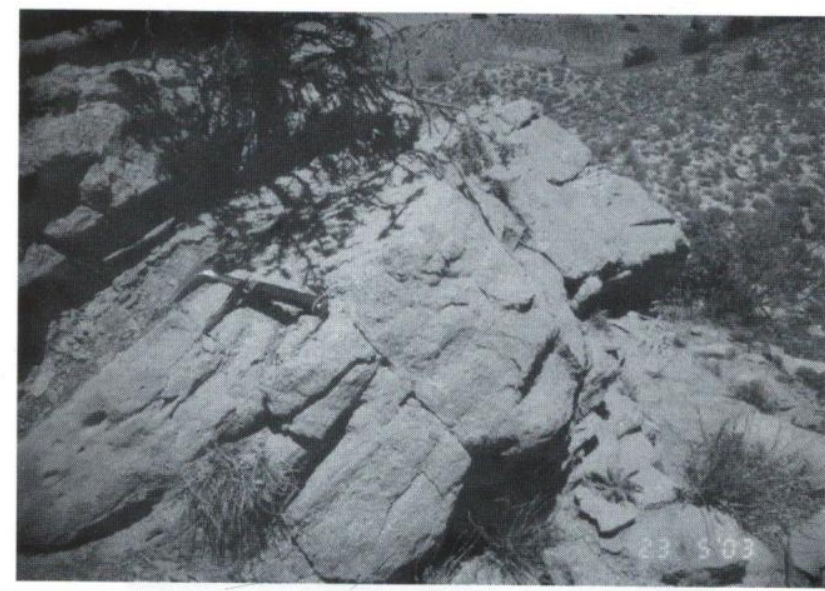

Fig. 5a: Interbedded shale and sandstone in the Dhok Pathan Formation

of the Siwalik sediments of continental origin followed. The Nagri Formation was deposited in a braided channel system. The coarse sandy units exhibit lenticular bedding and cutand-fill structures. With the passage of time, the braided channel system changed gradually to the meandering river system represented by the Dhok Pathan Formation. After the deposition of the Dhok Pathan Formation, the supply of coarse sediments (i.e., pebbles) started from the nearby areas, and the Soan Formation was deposited in the proximal part of a braided river channel.

\section{STRUCTURAL FEATURES}

The area underwent intense deformation giving rise to various folds, faults, unconformities, joints, and fissures. There are also many landslides. The Cretaceous period was a time of great tectonic instability. As a result, regional-scale folding and faulting of the strata took place and this event is known as the pre-Siwalik tectonic activity. Likewise, the postSiwalik tectonic activity caused the greatest and the most widespread deformation of rocks in the Balochistan sedimentary basin.

The Obushtakai Anticline (Fig. 3) and Zharai Syncline are the main structural features of the area. The NW-SE trending Obushtakai Anticline lies between the Zarghun Ghar and Sor Range, and the asymmetric and doubly-plunging Zharai Syncline is located further southwest. The north limb of the asymmetrical Obushtakai Anticline is exposed at the village of Maidad Zai, whereas the south limb is observed near the village of $Z$ harai. The anticline has the incompetent claystone and siltstone successions of the Ghazij Formation in its core and thick-bedded and competent limestone of the Kirthar Formation in its limbs (Fig. 3). The Serki Member of the Kirthar Formation is present in the core of the Zharai Syncline. The Habib Rahi Limestone is found in the overturned south limb of the syncline, which is also cut off by a major thrust.

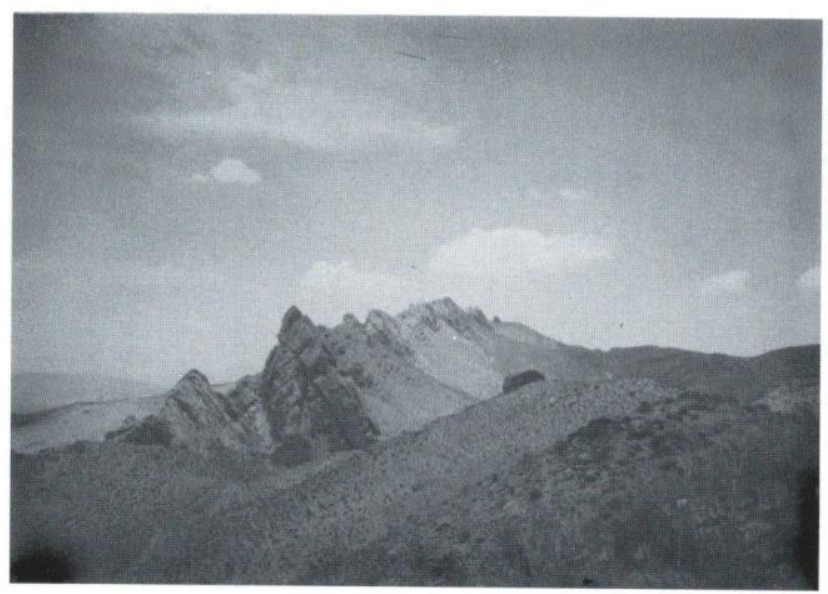

Fig. 5b: A strike-slip fault in the study area

Another major geological feature is the NW-SE trending Dokan Thrust-Wrench Fault Zone within the north limb of the Obushtakai Anticline. It is a broad and complex zone containing many other minor thrusts and wrench faults. The Dokan Thrust, Ushbul Thrust, and Dokan Strike-Slip Fault Zone near the Maidad Zai village are the important ones. The Ushbul Thrust brings with it the Jurassic Chiltan Limestone and the Cretaceous Parh Limestone, Fort Munro Formation, Pab Formation, and Dugan Formation in contact with the early Eocene Ghazij Formation. The north limb of the Obushtakai Anticline is disrupted by the Dokan Thrust. Consequently, the Ghazij Formation meets directly with the Serki shale member of the Kirthar Formation. The Dokan Strike-Slip Fault Zone contains at least five right-lateral faults. The faults have ramified the Habib Rahi Limestone Member at various places. The limestone is brecciated and fractured in the fault zone (Fig. 5c).

An angular unconformity separates the Serki Member of the Kirthar Formation of Middle Eocene from the Nagri Formation of Middle to Late Miocene. The change from marine shale and mudstone facies of the Serki Member to fluvial sandstone, mudstone deposits of the Siwalik Group and the difference in dip angle between the Kirthar Formation and Siwalik Group is the clear evidence of this unconformity.

In the mapped area, various joint sets are developed, especially in the Habib Rahi Limestone, Dhok Pathan Formation, calcareous sandstone of the Serki Member, and the Kirthar Formation.

\section{LANDSLIDE OCCURRENCE}

Landslides have caused great damage to the life and property as well as the natural environment around the world. Wentworth (1943), Terzaghi (1950, 1962), Zaruba and Mencl (1969), Swanston and Dryness (1973), Bagoora (1998), Panizza (1991), Matula (1969), Agrawal and Verma (1980), Valdiya and Bartarya (1984), Kattlemann (1987), Rajesh (1988), 


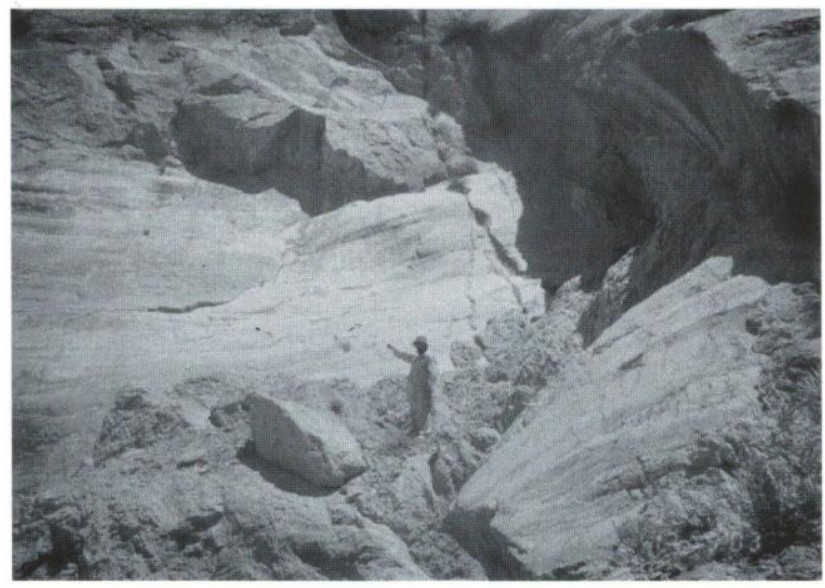

Fig. 5c: A fault scarp along a strike-slip fault in the Habib Rahi Limestone

Ramana and Gogte (1990), Narula (1992), Panchauri and Manjo (1992), Bartarya and Shah (1995) have carried out various studies on landslide. Accurate mapping of ancient landslides together with the study of slope conditions and bedrock geology should prove to be a valuable aid in determining slope stability on a regional basis. Waston (1971) and Kojan et al. (1972) emphasised the importance of aerial photo interpretation and landslide mapping for regional reconnaissance studies. Such studies are also useful for evaluating the relative distribution of active landslides and ancient landslide deposits.

The factors related to the landslide occurrence are the bedrock geology, slope conditions, precipitation, groundwater conditions, and seismicity. Therefore, an analysis of slope stability is required wherever the development plans are to be carried out.

Landslide susceptibility mapping of the study area was carried out on a scale of 1:50,000 mainly to delineate the existing and old landslides. Landslides occurring in the area are mostly slides and slumps. They are associated mainly with the slopes of the Ghazij Formation and overlying Kirthar Formation. They are mainly confined to a thick (over $1000 \mathrm{~m}$ ) succession of dominantly claystone and siltstone interbedded with minor sandstone, conglomerate, and coal seams. The presence of wide gapping fissures (Fig. 6b) near the peak of the Kirthar Formation and other ancient landslides of fairly large size and several small ones involve millions of cubic metres of rock mass and pose a high risk to the life and property. The fissures on the north-western side of the area indicate a progressive subsidence of the limestone mass. It is evidenced by a progressive decrease in the dip angle of strata across the fissures from the foothills to the peak. It may be a response of the human activities down slope, especially excavations of coal and other materials. The fissures between the highest reaches of the peak just above the westward-facing escarpments are nearly $1 \mathrm{~km}$ long

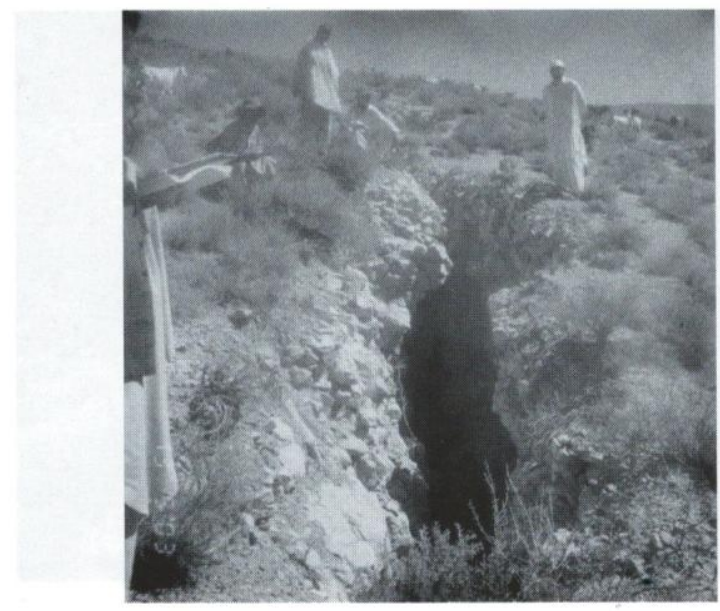

Fig. 6a: A deep and wide fissure in the Kirthar Formation

(Fig. 6c). They have a maximum width of nearly $250 \mathrm{~m}$ (Fig. 6b) with an average width of about $120 \mathrm{~m}$, and an estimated covered area of about $130,000 \mathrm{~m}^{2}$. If the average thickness of the Habib Rahi Limestone member of the Kirthar Formation is taken as $175 \mathrm{~m}$ (Mohsin et al. 1991), a rough estimate of the volume of limestone alone in the covered area will be at least 21 million cubic metres.

Fissures have been observed further westwards, down slope, above the coalmines, which indicate movements in the past. Near the western peak, the sides along fissures have moved down slope. These open fissures obviously receive all the surface runoff and the sediment load which lubricates the slip zones along the fissures.

The ENE-SSW trending active faults are substantially contributing to landslides. Keefer (1994) carried out an extensive study of the earthquake-induced landslides. Earthquakes have played a major role in initiating and triggering landslides in the study area. The disastrous Quetta earthquake of 1935 triggered many landslides in the area north of the Sor Range. The fresh landslides induced by the earthquake indicate that those slopes were in a state of limiting equilibrium at the time of ground shaking. Pre-earthquake slides were also reactivated indicating that the process of slope stabilisation was not complete during the earlier landslide activity. On the other hand, the old landslides apparently unaffected by the earthquake indicate that these slopes were stable at least for the particular intensity of earthquake.

In the Sor Range, most of the annual rainfall and snowfall occurs between December and March. During that period, the runoff causes erosion and development or reactivation of landslides. The presence of several ancient landslides of fairly small size is another factor, which probably indicates that they may be moving intermittently over a long period of time (Fig. 6a). 


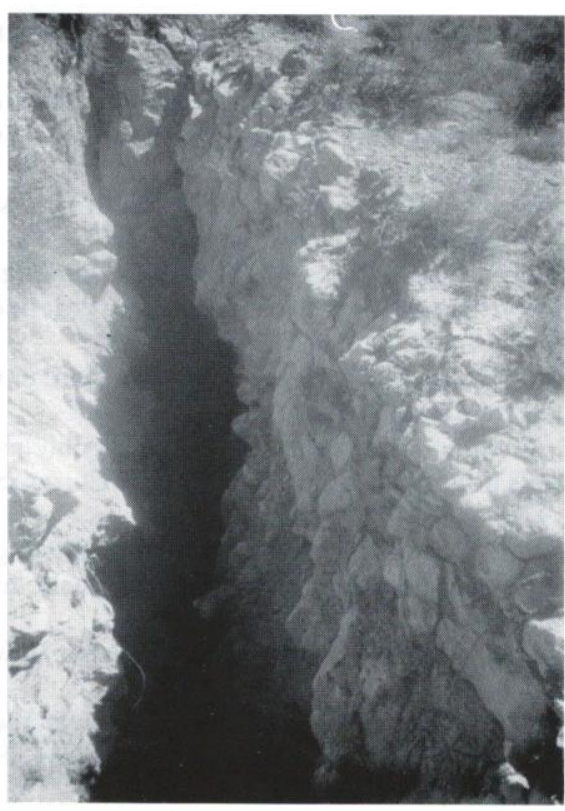

Fig. 6b: A wide fissure in the Kirthar Formation

Slides are caused by human activities in several ways. One being that the support at the toe of the slope is removed. Most oftenly, this occurs when construction is being done at the base of the slope. Many landslides have resulted from the modification of natural slopes commonly in areas that might at first appear to be stable (Nelson et al. 1976). Human activities like mining, cutting and removal of material from the slopes, and pumping out of mine water also have adversely affected the slopes. In the Sor Range, more than 5 million tons of coal have already been excavated (Mohsin et al. 1991). This must have caused subsidence of the overlying mass of the upper Ghazij Formation and the Kirthar Formation. The mines use explosives for mining purposes. Repeated explosions must have caused vibrations and shaking of the surrounding rocks. The Ghazij Formation has virtually no protection against erosion, since there is no vegetation protecting the ground and binding the soil to the bedrock.

\section{CONCLUSIONS}

The ancient landslides, steep slopes on the Ghazij Formation, and the presence of thick limestone of the Kirthar Formation forming nearly vertical cliffs over a thick incompetent argillaceous succession of the Ghazij Formation are some of the main factors triggering instabilities in the Sor Range. A comparison of these factors with those of the slope stability categories of Nelson et al. (1979) indicates that the area is highly susceptible to landsliding and hence is inappropriate for urban development. The existence of ancient landslides in the area indicates that similar landslides

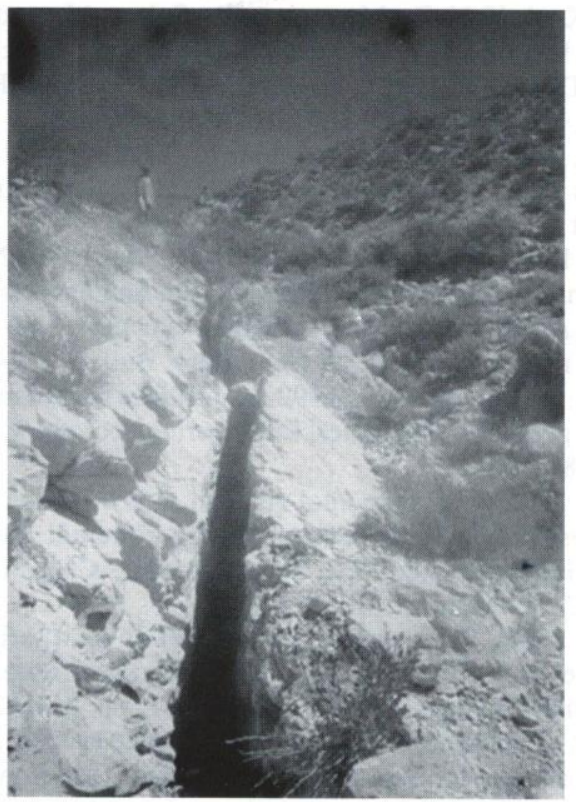

Fig. 6c: An extensive fissure in the Kirthar Formation

may also continue in the future. Therefore, a detailed investigation is necessary before constructing any structures on the slopes.

\section{REFERENCES}

Agrawal, V. K., and Verma, R. S., 1980, Qualitative analysis, stability and treatment of cut slopes of the proposed Jammu- Udhampur railway alignment. Proc. Inter. Symp. on Landslides (ISL 80), New Delhi, v. 1, pp. 45-48.

Bagoora, F. D. K., 1998, Soil erosion and mass wasting risk in the highland area of Uganda, Mountain Research and Development, v. 8 , no. $2 / 3$, pp. $173-182$.

Bartarya, S. K and Saha, M. P., 1995, Landslide induced riverbed uplift in the Tal Valley of Garhwal Himalaya, India. Geomorphology. v. 12, no. 2, pp. 109-121.

HSC (Hunting Survey Corporation), 1960, Reconnaissance Geology of part of West Pakistan: A Colombo Plan Cooperation Project, Toronto, Canada, 550 p.

Kakar, D. M. and Kassi, A. M., 1997, Lithostratigraphy, sedimentology and petrology of the Ghazij Formation, Sor Range Quetta District, Pakistan: Acta Mineralogica Pakistani, v. 8 , pp. $734-85$.

Kazmi, A. H., 1979, The Bibai and Gogai Nappes in the Kach-Ziarat area of Northeastern Balochistan: In Farah, A. and DeJong, K. A., (eds.), Geodynamics of Pakistan: Geological Survey of Pakistan, Quetta, pp. 333-340.

Kojan, E., Foggin, G. T. 3, and Rice, R. M., 1972, Prediction and analysis of debris slide incidence by photogrametry, Santa Vnez-San Rafel Mountain, California: Internat. Geol. Cong., 24th Proc. Sec. 13, pp. 124- 131.

Matula, M., 1969, Regional engineering geology of Czechoslovak Carpathian, publishing house Slovak Academy of sciences, Bratislava. 
Mohsin, A. K., Asif, N. R., Memon, A. R., Salem, M., and Khan, A. L., 1991, Coal resources of Sor Range Block, Sor Range- Degari Coal Field, Balochistan, Pakistan: Inf. Release No. 463, Coal Resources, and Geol. Surv. Pakistan.

Narula, P. L., 1992, Review of work done by landslides and seismo tectonics division. Records of Geological Survey of India. v. 125, part B, pp. 179.

Nelson, T. H., Taylor, F. A, and Dean, R. M., 1976, Natural conditions that control land sliding in the San Francisco Bay Region- An analysis based on data from the 1968-69 and 1972-73 rainy seasons: U. S. Geol. Surv. Bull, v. 1424, 35p.

Panchauri, A. K. and Manoj, P., 1992, Land slides hazard mapping based on geological attributes. Engineering geology, v. 32, no. 1-2, pp. 81-100.

Panizza M., 1991, Environmental risks in man's impact on the dolomites, Proceedings, European experimental course in applied Geomorphology, v. 2, Editors, Panaizza, M., Solidatti, M. and Cottellacci, M. M., pp. 7-12.

Rajesh, A., 1988, Preliminary geological investigations of Landslides along Dimapur-Mao road, Nagaland state, India. Bull. Indian Geologists Assoc. v. 21, no. 2, pp. 2519-2533.

Ramana, Y. V. and Gogate, B. S., 1990, Catastrophic landslip activity in two hard rock terrains of peninsular India. Environmental Geology and Water Sciences, v. 15, no. 3, pp. 199-205.

Reneau, S. L. and Deiotrich, W. E., 1987, Size and location of the colluvial landslides in steep forested landscape, In: Erosion and sediment transmit in Pacific Rim steep lands. Proc. Int.
Assoc. of Hydro. Sci., Chiristchurch symposium. LAHS publication no. 132 , pp. 362-374.

Sharan, R. B., 1992, Landslide hazard zonation in parts of Chenab River valley, Jammu and Kashmir. Rec. of Geol. Surv. India, part B, pp. 182-183.

Swanston, D. N. and Dyrnes, C. T., 1973, Stability of steep land. Jour. of Forestry, v. 11, No. 5, pp. 264-269.

Terzaghi, K., 1950, Mechanics of Landslides. In: Paige, S. (ed.) Application of geology to Engineering Practice (Berkly volume). Geol. Soc. of America, pp. 83-123.

Terzaghi, K., 1962, Stability of steep slopes on hard unweathered rock. Geotechnique, v. 2, no. 4, pp. 251-270.

Valdiya, K. S. and Bartarya, S. K., 1984, Problems of Mass movements in a part of Kumaun Himalaya. Current Science, v. 58, no. 9, pp. 486-491.

Watson, F., 1971, A preliminary report on new photo geological studies to detect unstable natural slopes. Quart. Jour. Engg. Geol., v. 4, pp. 133-137.

Wentworth, C. K., 1943, Soil avalanches on Oahu, Hawaii. Geol. Soc. of America Bull., v. 54, pp. 53-64.

Williams, M. D., 1959, Stratigraphy of the lower Indus basin, Pakistan. Proc. 5th World Petroleum Congress, New York, Proc., Sec. 1, 19,337-391.

Zaruba, Q. and Mencl, V., 1969, Landslides and their control. Elsevier, New York and Academia, Prague, pp. 157-158. 